\title{
Panurge's Quest and the Sixteenth-Century Idea of the Labyrinth
}

Hozumi Orii

\section{(2) OpenEdition}

12 Journals

\section{Electronic version}

URL: http://journals.openedition.org/studifrancesi/1190

DOI: 10.4000/studifrancesi. 1190

ISSN: 2421-5856

\section{Publisher}

Rosenberg \& Sellier

\section{Printed version}

Date of publication: 1 December 2015

Number of pages: 450-464

ISSN: 0039-2944

\section{Electronic reference}

Hozumi Orii, "Panurge's Quest and the Sixteenth-Century Idea of the Labyrinth", Studi Francesi [Online], 177 (LIX | III) | 2015, Online since 01 December 2016, connection on 06 January 2021. URL: http:// journals.openedition.org/studifrancesi/1190 ; DOI: https://doi.org/10.4000/studifrancesi.1190

\section{cc) (ㅇ) $\ominus$}

Studi Francesi è distribuita con Licenza Creative Commons Attribuzione - Non commerciale - Non opere derivate 4.0 Internazionale. 


\title{
Panurge's Quest and the Sixteenth-Century Idea of the Labyrinth
}

\begin{abstract}
Rabelais's Tiers Livre is sometimes described as a labyrinth of signs. Is it, then, based on the idea of the labyrinth? If, as some researchers assert, this narrative has a concentric structure, then it is similar in form to the traditional church labyrinth. However, an important difference exists in that church labyrinths suggest Christ's Harrowing of Hell, whereas Panurge, the antihero of the Tiers Livre, neither descends into the underworld nor combats the Devil, but is instead seduced by him. This paper contends that Rabelais, on the basis of the concept of the labyrinth, has substituted hell with earthly life and Christ, the combatant hero, with a cowardly antihero. To confirm this hypothesis, this paper analyses the representations of the underworld, the Devil and the sword in Rabelais's narrative fiction. In parallel, it investigates the influence of Erasmus' Enchiridion, focusing on its view of this life as a labyrinth, and contrasts Panurge's words and actions with the Erasmian ideal of the Christian soldier. Finally, it proposes a new interpretation of the praise of the herb Pantagruelion, comparing Rabelais's description of the plant with the flight of Daedalus from the Cretan labyrinth and with the resurrection of Christ from the underworld.
\end{abstract}

In Rabelais's Tiers Livre de Pantagruel Panurge worries about whether to get married $^{1}$. At his master's recommendation, he attempts various divinations and seeks advice from sages. However, he fails to achieve a satisfactory resolution and remains in a quandary until the end of the tale. François Rigolot comments that the entire Tiers Livre endlessly revolves around a single problem, calling it a textual labyrinth ${ }^{2}$. If so, were these features deliberately constructed? Did Rabelais intend to create a labyrinthine text? According to Rigolot, he was probably inspired by Jean Bouchet's Le Labyrinthe de Fortune and its influence is especially apparent in the episode regarding Panurge's dream. However, the Tiers Livre may be more deeply based on the idea of the labyrinth than Rigolot believes.

In Greek mythology, a labyrinth appears as a structure designed to imprison the Minotaur which was eventually slain by Theseus. Because of this myth, the Minotaur or the battle between Theseus and the Minotaur was often depicted at a labyrinth's centre during Roman times. Christianity, too, gradually adopted the motif of labyrinths, which increasingly began to appear on cathedral floors, especially from the thirteenth century onwards. The introduction of labyrinths into Christian culture is related to the Apocryphal Gospel of Nicodemus, which claims that Christ entered the underworld during the time between his crucifixion and resurrection, bound Satan in chains and freed the imprisoned souls. Labyrinths had symbolized not only prisons

(1) References to the Tiers Livre are from the critical edition by Jean Céard. RaBeLAIs, Le Tiers Livre, Paris, Librairie Générale Française, 1995 (hereafter TL). All translations are the author's, except where otherwise noted.
(2) F. RigOLOT, Le labyrinthe du songe-mensonge: de la "Fortune" de Bouchet au "Tiers Livre" de Rabe lais, in Les Grands Jours de Rabelais en Poitou, ed. by M.-L. Demonet, Genève, Droz, 2006 («Études rabelaisiennes», 43), pp. 119-132. 
but also the underworld since antiquity ${ }^{3}$, and with the Christianization of Greek and Roman mythologies, they seamlessly came to signify Christ's Harrowing of Hell ${ }^{4}$. In the Middle Ages and the Renaissance, a labyrinth would have conjured up images of an armed warrior descending into the underworld to battle the Devil. This was due to its direct or indirect associations with heroes regarded as foreshadowing Christ, such as Theseus, who slew the Minotaur in the labyrinth; Hercules, who extracted Cerberus from the underworld and Aeneas, who also descended into the underworld and returned victorious.

These elements are also present in the Tiers Livre. First, this book alludes frequently to the underworld or the act of descending into the underworld (for example, the stone of Sisyphus, the puncheon of the Danaids, the fictitious book De patria diabolorum, the golden bough, the Sibyl of Panzoust, Dathan and Abiram, Proserpina's close-stool and Demogorgon's black chamber). In particular, Chapter 23 centres on abduction by devils. Second, the story makes countless references to devils, who permeate the narrative, although the characters rarely discuss actual battle with them. This is unsurprising since, as Pantagruel points out, Panurge is seduced by the Devil: «L'esprit maling vous seduyt» (TL, 187). Third, arms and war are the story's recurring themes; the prologue, for instance, extensively lists weaponry and armour and glorifies war, while the story's body demonstrates an interesting concern with its avoidance. Along with his desire to get married, Panurge expresses his intention to withdraw from military service and lays down his arms. The combination of the three themes - descent into the underworld, seduction by the Devil and renunciation of arms - renders a portrait of a cowardly antihero who will not combat the Devil. His disavowal of warfare reveals his inability to wield his inner sword and results in spiritual disarmament. The descent into the underworld and battle with the Devil may, therefore, be regarded as the story's framework. Hence, the connection between the Tiers Livre and the labyrinth, especially the church labyrinth, merits examination.

Edwin Duval argues that the Tiers Livre is organized symmetrically around Chapter $25^{5}$. If so, we may indeed compare the book's structure to a traditional labyrinth, which has a centre point and is roughly symmetrical (fig. 1). Some researchers, however, dispute Duval's theory: Marie-Luce Demonet, among others, considering a historical change in the concept of the labyrinth, asserts that Rabelais's works lack a centre point $t^{6}$. Labyrinths, which had been unicursal during the Middle Ages, underwent secularization and diversification in the second half of the sixteenth century, when they increasingly began to exhibit forks and dead ends. According to Demonet, Rabelais's works are comparable to the later, more complex concept of the labyrinth and therefore have no fixed centre. However, this argument is misleading because whether unicursal or multicursal, nearly all labyrinths of the time had a centre point. Further, to obtain greater insight into this story's structure, we must focus on traditional church labyrinths as Panurge's relationship with the Devil is a major theme of the story. Interestingly, labyrinths symbolized not only Christ's Passion but also uncontrolled human passions. Also noteworthy is that this story begins with one of Christ's last words on the cross, consummatum est. It is, therefore, conceivable that

(3) In Virgil's epic poem, for example, a labyrinth adorns the door of the temple visited by the hero prior to journeying to the underworld ( $A e$ neid, 6.27).

(4) C. WRIGHT, The Maze and the Warrior: Symbols in Architecture, Theology, and Music, Cambridge, MA, Harvard University Press, 2001, pp. 37-86.
(5) E. Duval, Panurge, Perplexity, and the Ironic Design of Rabelais's "Tiers Livre", «Renaissance Quarterly», XXXV, 3, 1982, pp. 381-400.

(6) M.-L. Demonet, Les textes et leur centre à la Renaissance: une structure absente?, in La Renaissance décentrée, ed. by F. Tinguely, Genève, Droz, 2008, pp. 155-173. 
Rabelais has, on the basis of the labyrinth metaphor, replaced hell with earthly life and Christ, the combatant hero, with a cowardly antihero.

\section{Panurge's quest and the theme of descent into the underworld}

The connection between Panurge's quest and the theme of descent into the underworld has already received some attention. Marcel Tetel studied De patria diabolorum, a fictitious book that appears in the discourse of Panurge, and stated that the Tiers Livre follows Panurge's descent into the underworld'. Florence Weinberg focused on the structural similarity between the Tiers Livre and the Aeneid's sixth book: «There is a circular structure in the Aeneid: the hero's katábasis, his journey to Hades and back again. Panurge's itinerary through the Tiers Livre imitates the sixth book of the Aeneid in that it, too, is a katábasis» ${ }^{8}$. Her interpretation is particularly noteworthy because it may explain both the ideological link and structural similarity between the Tiers Livre and the labyrinth.

The beginning of the story depicts Panurge's rule of his castellany Salmigondin, noting that he squanders several years' income in two weeks through incessant banqueting. Pantagruel warns him against extravagance by telling him the story of a man named Albidius, who set fire to his own house after squandering all his wealth solely because he wanted to say consummatum est. These words, however, were also Jesus' final words before he was crucified. In addition, Pantagruel likens Panurge's great feasts to «l'aigneau Paschal». The Book of Exodus explains that when the Lord slew the firstborn of Egypt, He instructed the Jews to kill one lamb per family and devour it by morning. He further specified that they were to burn any leftovers and sprinkle the lamb's blood on the doorposts of their houses to avoid calamity. This story is regarded as foreshadowing the sacrifice of Jesus, the Lamb of God, on the cross. The combination of the phrases «l'aigneau Paschal» and «consummatum est», therefore, suggests Christ's death, and we may infer that the passage is intended to highlight the difference between Panurge and Christ. Viewed in this light, it is scarcely accidental that the antihero praises debts and debtors in subsequent chapters. Just as his selfish extravagance (tout est consommé) contrasts with the Saviour's self-sacrifice (consummatum est), so his paradoxical economy, founded on debts, can be regarded as an inversion of the economy of redemption'. Thus, the Tiers Livre starts not only with Panurge's extravagance and debts but also, on a deeper level, with Christ's crucifixion and redemption, which suggests that the former's itinerary through the story should be compared and contrasted with the latter's Passion and descent into the labyrinthine underworld.

The scene immediately prior to the first divination also has profound implications. First, Pantagruel describes the use of dice to predict one's future as the Devil's bait. However, Panurge disregards the danger and regularly carries dice with him, even considering them an amulet: «C'est le verd du Diable, comme expose Merl.

(7) M. Tetel, Rabelais et Folengo. "De patria diabolorum", in Rabelais en son demi-millénaire, ed. by J. CÉARD and J.-Cl. Margolin, Genève, Droz, 1988 («Études rabelaisiennes», 21), pp. 203-211.

(8) F. Weinberg, Panurge's Route Down and Out in the "Tiers Livre": A Katábasis, in Rabelais in Context, ed. by B.C. Bowen, Birmingham, AL, Summa, 1993, pp. 3-19.
(9) Edwin Duval notes, «In the Latin of the Vulgate, Christ's metaphors of "debts", "debtors", and "remission from debt" are of course perfectly congruent with the economy (and the vocabulary) of salvation, since "redemption" is literally nothing more than a "buying back", a "paying off", or a "ransom" (redimo <re-emo)». E. DuvAL, The Design of Rabelais's "Tiers Livre de Pantagruel", Genève, Droz, 1997 («Études rabelaisiennes», 34), pp. 49-50. 
Coccaius libro secundo de patria diabolorum. Le Diable me prendroit sans verd, s'il me rencontroit sans dez» (TL, 117). This statement clearly indicates Panurge's inability to resist the Devil's temptations. He carries the dice to ward off devils; however, ironically, his reliance on them attracts evil spirits who wish to carry him to their realm. Next, Panurge casts the dice and vows to charge into the devils if his interpretation is mistaken: «Je me donne à travers tous les Diables, comme un coup de boulle à travers un jeu de quilles ou comme un coup de canon à travers un bataillon de gens de pied» (TL, 117). Significantly, the verb se donner also implies devoting oneself. Pantagruel's reply, therefore, is not coincidental: «ja besoing n'estoit en faire si horrificque devotion» (TL, 117). Bewitched by the Devil's bait, Panurge charges towards it to embrace rather than attack it.

The second divination is an oneiromancy. Here Pantagruel remarks that «l'Ange maling et seducteur au commencement resjouist l'homme, en fin le laisse perturbé, fasché et perplex» (TL, 151). Although the reference is to Panurge's dream, it also reveals the reason why he gets lost in the labyrinth of signs. Not completely understanding the nature of the Devil's temptations, he falls into its trap and becomes increasingly perplexed. The theme of descent into hell is even more evident in the next episode in which a sibyl appears and the golden bough carried by Aeneas on his journey into the underworld is mentioned. The Sibyl of Panzoust closely resembles a witch, prompting Panurge to fear the impending onset of the devils: «il m'est advis que je oy Proserpine bruyante; les Diables bien toust en place sortiront» (TL, 173). Following this, Panurge meets a deaf-mute, Nazdecabre, whose name means goat's nose. His name is significant because Satan was often represented as a goat and evil spirits were sometimes believed to be deaf and mute. We may, therefore, interpret that the Devil lurks behind or within Nazdecabre ${ }^{10}$. The situation worsens when Panurge consults Raminagrobis. The entire encounter appears to abound with devils. Panurge believes that the old poet is slandering the mendicant friars and declares that his soul will be carried away by devils and fall into hell: «Sçavez vous où? Cor Bieu, mon amy, droict dessoubs la scelle persée de Proserpine» (TL, 219). However, Panurge himself fears being taken by devils, and therefore his words ironically betray his condition.

In a conversation with Epistemon, Panurge proposes a voyage to seek the oracle of Saturn, who he claims is in the Ogygian Islands, «lié de belles chaines d'or dedans une roche d'or, alimenté de ambrosie et nectar divin» (TL, 237); he thus shows himself to be fascinated by this pagan god. The myth surrounding Saturn is decidedly paradoxical: on one hand, he represents the primeval utopia that existed during the Golden Age, over which he ruled; on the other hand, he closely resembles Satan, having castrated his father Uranus with a sickle and devoured his own children. Further, he was later imprisoned in Tartarus by his son Jupiter. Satan is also double-faced and imprisoned in Tartarus. It is, therefore, probable that the reference to Saturn, bound in chains on the Ogygian Islands, alludes to Satan, bound in chains in the depths of hell.

Panurge's consultation with the Faustian occultist Her Trippa happens approximately near the centre of the story. Of all the divinatory episodes, this one, with its sinister atmosphere, brings Panurge closest to the Devil ${ }^{11}$. The occultist proposes

(10) See Jean Céard's introduction to the Tiers Livre (TL, xxi).

(11) Jean Céard comments that «jamais Panurge n'a éprouvé si vivement l'impression d'avoir visité quelque antichambre de l'enfer». J. CÉARD, $\mathrm{La} \mathrm{Na}$ ture et les prodiges, Genève, Droz, 1996, p. 147.
Timothy Chesters calls the consultation with Her Trippa «the most unambiguously diabolical encounter in the Tiers Livre». T. CHESTERS, Ghost Stories in Late Renaissance France, Oxford, Oxford University Press, 2011, p. 194. 
nearly forty dubious, bizarre and even unpleasant divination methods, including necromancy, in quick succession. Panurge detects the Devil's scent on him and declares him a madman served by evil spirits. He goes on to call Her Trippa a wizard of the Antichrist and a long-robed devil, finally exclaiming, «Vray Dieu, comment il m'a perfumé de fascherie et diablerie, de charme et de sorcellerie!» (TL, 249). We may, therefore, infer that the antihero's meeting with the demonic occultist constitutes the centre of this textual labyrinth. Previous studies on labyrinths have noted that Theseus' encounter with the Minotaur at the labyrinth's centre can, on a deeper level, be regarded as an encounter with the unconscious aspects of one's own existence ${ }^{12}$. Her Trippa foretells the infidelity of Panurge's future wife, but the occultist is entirely unaware of his own wife's deception. As for Panurge, he criticizes Her Trippa: «Il ne sçait le premier trait de philosophie, qui est CONGNOIS TOY» (TL, 243). However, this principle is also the key to solving his own problem. Thus, in essence, Panurge is unknowingly confronting his own shadow. The episode of Her Trippa is, therefore, appositely placed at the story's centre point.

Panurge's subsequent conversation with Frère Jean serves to recapitulate the story's first half. Here Panurge recounts the events that occurred when he watched the Passion Play. He claims that everyone present became sexually aroused by the magical power of his codpiece and the actors playing the devils started having intercourse with the spectators. His story clearly reflects his own relationship with the Devil. Following this, Frère Jean tells the story of a jeweller named Hans Carvel, who had long been worried about his wife's faithfulness. One night, the jeweller dreams that the Devil has given him a magic ring that would prevent his wife's infidelity; however, when he awakes, his finger is not inside a ring but inside his wife's private parts. This story also describes Panurge's condition because he not only shares Hans Carvel's worry but also has yielded himself to the Devil by foolishly indulging his misguided faith in divination and occult power. Thus, the next chapter begins a new stage of the story.

\section{The Tiers Livre and changing perceptions of the labyrinth}

Considering the aforementioned reasons, Panurge's itinerary through the Tiers Livre can indeed be seen as not only a wandering through the labyrinth (as pointed out by Rigolot) but also a descent into the underworld (as noted by Weinberg). In addition, the story starts with Christ's last words on the cross. Therefore, the Tiers Livre, based on the concept of the church labyrinth, may well describe the antihero's itinerary as an antithesis of Christ's descent into the labyrinthine underworld. This possibility is intensified by the work's concentric composition, which, moreover, places the story's most diabolical encounter at the centre. Although Panurge's perplexity remains unresolved in the story's second half, this does not contradict our hypothesis. Despite passing the centre, he remains in the labyrinth, and the journeys to and from the centre of a labyrinth are equally arduous because they are subject to identical entanglements. Therefore, it is only natural that Panurge faces difficulties until the end of the story. Furthermore, the principal subject of the Tiers Livre being marriage, Panurge's sexual desire drives the story. Note that the labyrinth and carnal passions have a historical association because the Minotaur was the offspring of Pasiphaës

(12) J. PIEPER, Das Labyrinthische: über die Idee des Verborgenen, Rätselhaften, Schwierigen in der Geschichte der Architektur, Basel, Birkhäuser, 2009, p. 43; H. Kern, Through the Labyrinth: Designs and Meanings over 5000 Years, trans. by A.H. CLAY, Munich, Prestel, 2000, p. 187. 
lust for a bull. This makes Chapter 34 particularly noteworthy as it precisely refers to Pasiphaë and other women who had intercourse with animals. Their uncontrolled curiosity and passion, too, seem to reflect Panurge's problem and suggest the reason why our antihero becomes lost in the labyrinth of perplexity ${ }^{13}$.

In the prologue as well, words and expressions related to the underworld assume importance. First, Rabelais compares his third book to Diogenes' barrel, which itself is likened to Sisyphus' stone. Then, he equates his book to the «rameau d'or sacré à la deesse soubsterraine» or the «couppe de Tantalus representé par figure entre les saiges Brachmanes». He continues: «Bon espoir y gist au fond, comme en la bouteille de Pandora: non desespoir, comme on bussart des Danaïdes» (TL, 29). These expressions indicate that the Tiers Livre is closely connected with endless labour in the underworld as well as with hope for liberation. Labyrinths have long been intimately associated with labour. Virgil highlighted the phonetic similarity between labyrinthus and labor, and medieval writers believed that labyrinth is derived from labor and intus, meaning labour within ${ }^{14}$. Rabelais probably had this tradition in mind.

Finally, the end of the story, in which the narrator refers to the invention of sails and the possibility of human flight, is also related to labyrinths, especially to the myth of Daedalus. As a matter of fact, Pliny the Elder - and later Polydore Vergil - attributes the invention of the sailboat to Daedalus and Icarus ${ }^{15}$. Rabelais was certainly aware of this. Thus, considering the foregoing analysis, we can reasonably estimate that the Tiers Livre constitutes a labyrinth.

Let us now consider the position of the Tiers Livre in the history of the labyrinth. During the late Middle Ages, the development of the doctrine on purgatory particularly added force to the story of Christ's descent into hell; thus, labyrinths began to appear on church floors and were associated with hell rather than earth ${ }^{16}$. However, a significant change occurred in the sixteenth century. The advent of the Reformation again transformed the concept of the labyrinth, undermining the authority of the Catholic Church and internalizing and personalizing matters of faith ${ }^{17}$. As a result, medieval connotations of the labyrinth regarding descent into the underworld and battling the Devil were gradually lost and replaced by implications of solitary human life in a world replete with sin. As Craig Wright notes, «the emphasis now begins to shift away from He to I, from Christ to the Christian, from Hell back to earth ${ }^{18}$, and it is against this background that, later, the metaphysical poet Henry King calls life «a crooked Labyrinth» and describes it as «a perplexed Circle, in whose round nothing but Sorrowes and new Sins abound» ${ }^{19}$.

(13) H. ORII, «Oncques ne feut faict soloecisme»: l'interprétation et l'image du membre viril dans le "Tiers Livre" de Rabelais, «Études rabelaisiennes», 44, 2006, pp. 31-46, especially pp. 43-45.

(14) W. Fitzgerald, Aeneas, Daedalus, and the Labyrinth, «Arethusa», XVII, 1984, pp. 51-65; P. REED DoOB, The Idea of the Labyrinth: From Classical Antiquity through the Middle Ages, Ithaca, NY, Cornell University Press, 1990, p. 97.

(15) Pliny, Naturalis historia, 7.56; Polydore Vergil, De inventoribus rerum, 3.15.10. See also Pausanias, Graeciae descriptio, 9.11.4-5. According to Pausanias, Daedalus invented sails, not wings, to flee Crete.

(16) C. Wright, The Maze and the Warrior, pp. 76-78.

(17) Ibid., pp. 86-100.
(18) Ibid., p. 86. See also H. DiEHL, Into the Maze of Self: The Protestant Transformation of the Image of the Labyrinth, «The Journal of Medieval and Renaissance Studies», XVI, 2, 1986, pp. 281-301.

(19) The Poems of Henry King, ed. by M. Crum, Oxford, Clarendon Press, 1965, p. 173. Note that Rabelais's contemporary Jean Thenaud, too, in his Le Triumphe de Prudence (1517), describes earthly life as a «difficil et perplex labirinte»: «O ma totalle esperance, affin que ne soye devoré du Minothaure infernal, qui rugist en cestuy labyrinthe ouquel suys plus que perplex et esgaré [...], te plaise m'envoyer le raidz plus resplendissant que le soleil de ta grace [... .» J. Thenaud, Le Triumphe de Prudence, ed. by T.J. Schuurs-Janssen, Genève, Droz, 1996, pp. $14-$ 19. See also S. GeOnget, La Notion de perplexité à la Renaissance, Genève, Droz, 2006, pp. 164-165. 
This change is corroborated by illustrations in several emblem books, including Guillaume de La Perrière's Le Theatre des bons engins (1539). La Perrière's labyrinth resembles the classic Chartres-type labyrinth, but a man in contemporary costume replaces the devilish beast usually found at the centre of those labyrinths (fig. 2$)^{20}$. This man is neither a hero nor a warrior; according to the corresponding poem, he is a mere mortal drowning in empty pleasures. Here it seems as if the fact that labyrinths once symbolized the underworld has been all but forgotten. Another example is an illustration in Herman Hugo's Pia desideria emblematis (1624), which depicts a pilgrim at a labyrinth's centre ${ }^{21}$. Thus, the warrior of the labyrinth had metamorphosed into a solitary pilgrim by the early seventeenth century at the latest ${ }^{22}$. As the Reformation progressed, church labyrinths steadily disconnected with Easter; liturgical dances that had been performed on church labyrinths were gradually abolished ${ }^{23}$, and from the seventeenth century onwards, church labyrinths were used solely for simulated pilgrimages. In the late sixteenth century, forks and dead ends began to appear in increasingly diverse garden labyrinths, and by the end of the century, multicursal labyrinths had become the norm, although garden labyrinths continued to retain a centre, irrespective of whether they were multicursal or unicursal. Garden labyrinths without centres did not appear in France until the seventeenth century, around the time of Louis XIV ${ }^{24}$.

Given the temporal background against which the Tiers Livre was written, we may assume that Rabelais's labyrinth has a centre, but we remain uncertain as to whether it is unicursal or multicursal. Panurge is faced with many interpretations and decisions, but this does not drive the book's structure in any particular direction. After all, he is seduced by evil spirits and therefore cannot freely choose his path. Furthermore, labyrinths in classic literary works are frequently described as quite complex structures, even when the works date from eras when all pictorial labyrinths were unicursal. Thus, literary multicursal labyrinths have coexisted with visual unicursal labyrinths since ancient times ${ }^{25}$. Considering the theme of descent into the underworld, the Tiers Livre is probably a traditional labyrinth similar to the type found on cathedral floors; however, at its centre is neither Christ nor a hero but a man who yields to the Devil's temptations. This work thus reflects the changing perceptions of the labyrinth in the sixteenth century. In addition, it also mirrors the changes in perceptions of the Devil that occurred during the Reformation, after which people were compelled to confront the forces of evil by themselves instead of trusting the church for protection as they had done during the Middle Ages ${ }^{26}$. Rabelais's narrative fiction ingeniously portrays a man placed in this position.

What, then, inspired Rabelais to create a labyrinthine text? François Rigolot believes that the Tiers Livre was influenced by Jean Bouchet's Le Labyrinthe de Fortune (1522). However, considering the story's theme, we suggest that Rabelais was inspired by Clément Marot's L'Enfer (c. 1526). This satirical poem is structured around three long, almost symmetrically arranged discourses: a commentary on the underworld (i.e. prison) by the minister of hell, the prisoner's interrogation by the

(20) H. KERN, Through the Labyrinth, p. 221; C. WRIGHT, The Maze and the Warrior, pp. 92-94.

(21) H. KERN, Through the Labyrinth, p. 209.

(22) C. Wright, The Maze and the Warrior, pp. 94-100, 207-216.

(23) To celebrate Christ's resurrection, the clergy performed a dance on the labyrinths of certain cathedrals as part of Easter ceremonies. This tradition continued until 1517 in Sens, 1538 in Auxerre and for even longer in Chartres. See C. WRight, The Maze and the Warrior, pp. 132-158.

(24) H. KERN, Through the Labyrinth, p. 265; C. WRIGHT, The Maze and the Warrior, pp. 228-230.

(25) P. ReEd Doob, The Idea of the Labyrinth, p. 41.

(26) J.B. Russell, The Prince of Darkness: Radical Evil and the Power of Good in History, Ithaca, NY, Cornell University Press, 1988, pp. 167-168. 
judge Rhadamanthus and the accused Marot's apologia ${ }^{27}$. Thus, its three prominent attributes are typical characteristics of labyrinths: descent into the underworld, an almost symmetrical structure and a confrontation with a Satan-like character in the centre. Several additional facts accentuate the similarities between L'Enfer and labyrinths. First, owing to the legend of the Minotaur, labyrinths may evoke the idea of prisons. Second, in the Middle Ages and the Renaissance, Virgil's underworld was undoubtedly regarded as a labyrinth ${ }^{28}$. Finally, L'Enfer contains a reference to Christ's Harrowing of Hell, which the church labyrinth symbolized. These factors suggest that Marot may have based the structure of L'Enfer on a labyrinth, and this would have influenced Rabelais as he was well acquainted with the poet. Like Marot, who remains detained until the end of the poem, Panurge is imprisoned by his dilemma until the end of the story. Considering these elements, the relationship between the two works deserves more attention. However, although L'Enfer superimposes real-world experience upon the journey into the underworld, it does not focus on individual perplexity. There may be yet another work that inspired Rabelais, as discussed in the following section.

\section{Panurge as an unarmed man and the Erasmian ideal of the Christian soldier}

In addition to symbolizing prisons and the underworld, the labyrinth signified the battleground for combat with the Minotaur or Satan. It is, therefore, unsurprising that the Tiers Livre contains many references to weapons and armour. For example, the prologue extensively lists weaponry while describing the preparations for a defensive battle in ancient Corinth, and the text makes several allusions to arms. Interestingly, however, the prologue's valiant atmosphere is missing from the story; on the contrary, Panurge finds war tedious and sheds his armour. Why is the difference between the two sections so significant? The answer possibly lies in the words of St. Paul, who explains that one must be armed to overcome the wiles of the Devil: «Put on the whole armour of God, so that you may be able to stand against the wiles of the devil. [...] fasten the belt of truth around your waist, and put on the breastplate of righteousness. [...] Take the helmet of salvation, and the sword of the Spirit, which is the word of God» ${ }^{29}$. Needless to say, St. Paul is speaking of armour in a spiritual sense. His words support the view that despite being in a labyrinth (which represents a battleground), Panurge has literally discarded his arms and, along with them, his spiritual armour and is therefore powerless against the Devil's temptations.

The theme of spiritual arms recalls Erasmus' Enchiridion militis Christiani (1503), a handbook on repelling the Devil's attacks. Interestingly, Erasmus uses the labyrinth as a metaphor for the sinful world.

We shall try to pass on briefly certain rules - some wrestling holds, one might say - with the help of which you can easily extricate yourself from the labyrinthine errors of this world and, using these rules like the thread of Daedalus, find your way into the clear light of spiritual living ${ }^{30}$.

(27) On closer inspection, the structure of the poem reveals further indications of subtle symmetry. See H. ORII, La structure de "l'Enfer" de Clément Marot, «Réforme, Humanisme, Renaissance», LV, 2002, pp. 7-24.

(28) P. REED Doob, The Idea of the Labyrinth, p. 239.
(29) Ephesians 6:11-17. All biblical quotations are from the New Revised Standard Version.

(30) Erasmus, Enchiridion, trans. by R. HimeLICK, Bloomington, Indiana University Press, 1963 (hereafter E), p. 83. 
Note that Erasmus has replaced Christ and the underworld with individual Christians and this world, respectively ${ }^{31}$. For him, the battle with the Devil occurred not in hell but here and now: «Like Virgil's Aeneas you should shrug off as nothing all the bogey men and fantasies that assail you, so to speak, in the very jaws of hell» $(\mathrm{E}, 90)$. Erasmus took the medieval concept of the labyrinth and recast Christ's battle with Satan as a battle within oneself. Signs of the new sixteenth-century perspective on labyrinths emerge in this book, which may be connected to the Tiers Livre.

Like the Tiers Livre, the Enchiridion advocates the importance of knowing oneself. Erasmus compares the wisdom of the world with that of Christ, saying of the latter, «The chief point of this wisdom is simply to know yourself» $(\mathrm{E}, 62)$. The Enchiridion posits that battling the Devil is equivalent to battling oneself; therefore, knowledge of oneself is paramount, for in that lies the hope of victory. On the basis of this thought, Erasmus introduces readers to St. Paul's dualism of the spirit and the flesh, urging them to live according to the former ${ }^{32}$. The Tiers Livre employs irony to impart a similar message. Panurge declares, «Oncques ne feut faict soløcisme par le vaillant champion qui pour moy faict sentinelle au bas ventre» (TL, 117). Because he relies on his physical desires for judgement and interpretation, he is unable to make proper decisions and succumbs to the Devil's temptations. According to Erasmus, people such as Panurge especially need to know themselves. As previously mentioned, the wisdom of Christ is the thread that guides one through the labyrinth, and it can be attained only through self-knowledge. Therefore, the words know thyself are aptly placed at the centre of this textual labyrinth.

Enchiridion means both handbook and dagger. Erasmus states, «I have fashioned for you an enchiridion, that is to say, a kind of hand dagger, which you should never put aside, not even at the table or in bed» $(\mathrm{E}, 58)$. He argues that our lives are an incessant battle with the forces of evil and his book is the sword needed for that battle. How, then, are sword and its synonyms treated in the Tiers Livre? Like Erasmus, Panurge insists that swords can fend off devils, citing the examples of Hercules and Aeneas, who carried a club and a sword, respectively, into the underworld. He also mentions a marshal named Trivulzi who, on his deathbed, requested a dagger so that his soul might defend itself on its journey to its final resting place. However, Panurge does not speak of spiritual swords; instead, he teases his friend, using the word bragmard, which means both dagger and phallus: «Nous parlons de harnoys fourbiz, et d'espées resplendentes. Ainsi n'est il de ton bragmard. Car par discontinuation de officier et par faulte de operer, il est par ma foy plus rouillé que la claveure d'un vieil charnier» (TL, 229). Since Panurge is complying with the dictates of the flesh, he is acting under the Devil's influence. His double entendre's vulgar meaning, therefore, hints at his relationship with the Devil.

Additional wordplay hinging on the sword's phallic connotations occurs in the episode of Nazdecabre, in which Panurge «monstroit le default de sa braguette: puys sous sa chemise print son pistolandier à plein poing, et le faisoit melodieusement clicquer entre ses cuisses» (TL, 197). Pistolandier, like bragmard, can mean both

(31) C. WRight, The Maze and the Warrior, pp. 86-90.

(32) «Man is a being of a most unusual sort, composed of two or three vastly unlike parts: a soul that is like something divine and a body like that of a dumb brute», asserts Erasmus (E, 63). In this context, it is interesting to note that the Minotaur has long been regarded as a figure for human bestiality. Pierre Dinet (1555-1595), for instance, re- marks: «Le Minotaure [...] participe de la creature raisonnable, et de celle qui est incapable de raison. Ce sont nos discours d'un costé, et de l'autre nos affections, et concupiscences, deux extrémes perpetuellement accouplez en nous, dans le labyrinthe de nostre vie pleine de discours, embroüillemens, et incertitudes [...].» P. Dinet, Cinq livres des biéroglyphiques, Paris, J. de Heuqueville, 1614, p. 385. 
dagger and phallus. As mentioned above, the Devil is probably manifesting through Nazdecabre; in its presence, Panurge is not only parading his lack of a codpiece but also brandishing his penis instead of a sword. Another reference to swords appears in the story's central episode, in which Panurge gifts Her Trippa «une grande espée bastarde bien dorée à fourreau de velours» (TL, 239). Having recently insisted that a sword can ward off devils, it is ironic that Panurge presents the Faustian occultist with an ornate but useless sword. Shortly after that, he takes offence at the outcome of the divinations and insults Her Trippa, but he remains under the Devil's influence. In fact, he disregards the true meaning of Jesus' words, «Why do you see the speck in your neighbour's eye, but do not notice the log in your own eye?»»3 , and, ironically, uses these words to inveigh against another. We thus observe that Panurge unwittingly abuses the sword of the Spirit. In his present condition, he would never be able to extricate himself from the labyrinth of perplexity.

Like Erasmus, Rabelais seems to be trying to teach his readers how to use spiritual weapons. This is evident from the prologue, which is filled with talk of war and words related to weapons, arms, ramparts and strongholds. It informs us that the Corinthians had learned that the Macedonian king was arriving with his great army and therefore they prepared for an attack. Everyone was armed and ready at their posts: «Chascun exerceoit son penard: chascun desrouilloit son bracquemard» (TL, 17). Likewise, everyone in France is mobilized to defend their fatherland. The movement is perfused with harmony, and Rabelais relates to the words of Heraclitus, «war is the father of all good things». In the sixteenth century, l'homme armé was often considered emblematic of l'âme armée $e^{34}$. It is conceivable that while talking about actual events, Rabelais simultaneously reflects on spiritual war $^{35}$. Furthermore, he declares that he himself is armed with a stick: «Voyez cy le baston que Diogenes par testament ordonna estre près luy posé après sa mort pour chasser et esrener ces larves bustuaires et mastins cerbericques» (TL, 31). This statement is strongly reminiscent of the anecdote of the marshal Trivulzi, which is not surprising given the story's underlying theme. Note that Rabelais again recounts another defensive battle in the concluding chapter's final part: according to the narrator, Julius Caesar's Roman army set fire to the Piedmont Castle's tower but failed to inflict any damage on it because it was built of larix, an incombustible wood. Similar to the prologue, this episode may allude to spiritual warfare. In fact, the narrator continues that Pantagruel uses this wood to protect the abbey of Theleme as well as the ships in his arsenal.

As previously explained, the story's main body speaks only of avoiding military service. In addition to the sword of the Spirit, St. Paul states that we must gird ourselves with the complete suit of holy armour. Panurge, too, recognizes the effectiveness of arms against devils when he notes that Aeneas was covered in shining armour, with the cutlass in his belt well furbished and cleaned of rust. However, Panurge himself is entirely unarmed, both spiritually and physically. He dons a toga, the garment of peacetime in ancient Rome, and declares, «Je suis las de guerre: las des sages et hocquetons. J'ay les espaules toutes usées à force de porter harnois. Cessent les armes, regnent les Toges» (TL, 87). Further, he insists that Nature created humans to enjoy peace, not war. Although this corresponds to Erasmus' view of peace ${ }^{36}$, the two do not concur on the subject of spiritual warfare. In fact, the following extract from the Enchiridion shows that their views are diametrically opposed:

(33) Matthew 7:3

(34) C. WRIGHT, The Maze and the Warrior, pp. 164-205.
(35) Compare, for example, with Zwingli's patriotic poem Der Labyrinth (1516).

(36) Erasmus, Adagia, 4.1.1. 
Since we are all engaged in such formidable and taxing warfare and have enemies so numerous, so committed to our destruction, so zealous, so vigilant, so well-armed, so treacherous, so skillful, are we not of dubious sanity if we, on our part, do not arm ourselves, stand on guard, and hold all things suspect? But just as if conditions were absolutely tranquil, we snore away flat on our backs; we do nothing, we enjoy ourselves and, as they say, idly look after our skins [...] You lunatic! You cry «Peace! Peace!» when you have God as your enemy, who alone is peace and the author of peace. (E, 39-40)

Erasmus' portrayal of the lazy, misguided fool who lays down his spiritual arms aptly describes Panurge, who comically runs from war yet declares his phallus a valiant champion. By removing his codpiece, «piece premiere de harnois militaire» (TL, 89), Panurge also discards his spiritual armour. His talk of furbished arms and bright swords only disguises the rustiness of his spiritual sword, and his defeat by the Devil is entirely predictable. Therefore, we may conclude that the Tiers Livre reflects Erasmus' view of the Christian life stated in the Enchiridion. Panurge is the antithesis of not only Christ but also the ideal Christian soldier, and his perplexity is depicted as a wandering through the labyrinth precisely in the Erasmian sense.

\section{«Bon espoir y gist au fond»: Christ, the Redeemer of the labyrinth}

Further consideration of the idea that the Tiers Livre emulates a labyrinth's structure reveals deeper layers of meaning in the work. As stated previously, this story starts with Christ's last words on the cross, consummatum est, which, combined with the expression «l'aigneau Paschal», implies his crucifixion. Given this beginning, it is noteworthy that the final chapter's title, «Comment certaine espece de Pantagruelion ne peut estre par feu consommée», contrasts sharply with consummatum est $t^{37}$. The praise of the asbestine Pantagruelion may, therefore, relate to Christ's resurrection. In fact, the description of the plant that is purified rather than burnt when thrown into fire powerfully evokes the mystery of the resurrection: while the paschal lambs were completely consumed and burnt, the Lamb of God sacrificed himself but, mysteriously, was never «consumed», for he descended into hell, vanquished Satan and rose again victorious. Moreover, since Christ is, according to Erasmus, «the author of wisdom, rather wisdom itself» $(\mathrm{E}, 59)$, it is not surprising that he is praised at the end of a story centred on the quest for truth. The Tiers Livre provides a conclusive lesson on the importance of recognizing the limitations of worldly wisdom and constantly seeking the wisdom of Christ because, after all, he is the sole and eternal Redeemer of the labyrinth.

In addition, the incombustible plant is also connected with labyrinths. Polydore Vergil, in his De inventoribus rerum (1499), discusses the invention of labyrinths and origin of cremation within the same chapter, in which he also refers to an incombustible linen cloth $^{38}$. As is well known, this work owes a great deal to Pliny's Naturalis historia, which reports that the funeral tunics of certain kings were made from incombustible linen to ensure the separation of the body's ashes from those of the pile ${ }^{39}$. At a separate instance, it states that certain ancient labyrinths were constructed as tombs for kings ${ }^{40}$. Therefore, to those familiar with Pliny's work, labyrinths were reminiscent of the ancient cremation practice and incombustible linen cloth. It is thus that Poly-

(37) F. Rigolot, Rabelais's Laurel for Glory: A Further Study of the Pantagruelion, «Renaissance Quarterly», XLII, 1, 1989, pp. 60-77.
(38) Polydore VergiL, De inventoribus rerum, 3.10

(39) Pliny, Naturalis historia, 19.4.

(40) Naturalis historia, 36.19. 
dore Vergil compiled these elements in one chapter, as Rabelais combined them in the last chapter of the Tiers Livre. Interestingly, Rabelais further associated these elements with Christ's resurrection. Although even monarchs and rulers such as Mausolus are inevitably reduced to ashes when thrown into fire, the asbestine Pantagruelion can emerge from it unscathed. This comparison with royalty renders the mysterious plant an appropriate allegorical representation of Christ and his resurrection ${ }^{41}$.

Thus, the book begins with the Saviour's crucifixion and ends with his resurrection. Note that he descends into the underworld between the time of his crucifixion and resurrection. Panurge's actions, therefore, follow those of Christ, but in a significantly different manner. For example, Panurge's economy, symbolized by extravagance and debt, is the exact opposite of Christ's economy of salvation, who settled the debts of humanity with his own death. At the book's centre, when Panurge misuses Jesus' words to criticize Her Trippa, his self-love contrasts sharply with Christ's charity. Also striking is the difference between Panurge's experience at the Passion Play and Christ's Passion. Rabelais, of course, uses the ambiguity of passion because, as previously noted, labyrinths symbolized not only the Passion but also carnal passions. Rabelais demonstrates this intentional ambiguity through two puns in the prologue: first, «Lapathium acutum de Dieu», which means God's sharp-pointed dock but suggests the Passion of Christ (lapathium was then pronounced la passion) (2) $^{42}$ second, «au cul passions», which means both occupations and passions in the ass ${ }^{43}$. The phonetic similarity between lapathium acutum and la passion à cul merits attention. With this play on words, Rabelais announces the story's main theme. Initially, Panurge's perplexity appears unrelated to Christ's Passion, but its significance becomes clear when it is compared with the latter. This comparison is warranted because the Tiers Livre is based on the idea of a labyrinth, which originally symbolized Christ's descent into the underworld.

Returning to the topic of the Pantagruelion, we note that previous studies have regarded this plant as a symbol of human wisdom. Madeleine Lazard states, «la plupart des critiques s'accordent à voir dans ce texte une apologie enthousiaste et optimiste du génie de l'homme et de son pouvoir» ${ }^{44}$. This idea is valid but incomplete, for Rabelais balances praise of human wisdom with hints of its limitations ${ }^{45}$. The Pantagruelion is a fantastic plant with many uses, including, however, harmful ones. A typical example is the sail, the invention of which, great though it is, can lead to destructive consequences. In fact, Pliny states that it is difficult to determine a curse

(41) A similar use of the figure of asbestos is found in St. Athanasius' De incarnatione Verbi. It states that just as the stubble wrapped with asbestos does not fear fire, so the body clothed with Christ does not fear death.

(42) «Envers les guerroyans je voys de nouveau percer mon tonneau [...] Je n'y fauldray par Lapathium acutum de Dieu» (TL, 25).

(43) «Les geants Doriphages avalleurs de frimars, ont au cul passions assez et assez sacs au croc pour venaison» (TL, 29).

(44) M. LAZARD, Rabelais et la Renaissance, Paris, PUF, 1979, p. 54. See also L. SAINÉAN, La Langue de Rabelais, Paris, De Boccard, 1922, I, pp. 25-27; V.-L. SAulnier, L'énigme du Pantagruélion, ou du "Tiers" au "Quart Livre", «Études rabelaisiennes», 1, 1956, pp. 48-72; D. Quint, Origin and Originality in Renaissance Literature. Versions of the Source, New Haven, CT, Yale University Press, 1983, pp. 167-206. Needless to say, there are many other readings. See, for example, Y. Delègue, Le Pantagruélion ou le discours de la vérité, «Réforme, Humanisme, Renaissance», XVI, 1983, pp. 1840; M.-L. Demonet, Polysémie et pharmacie dans le "Tiers Livre", in Rabelais et le "Tiers Livre", ed. by É. Kotler, Nice, Publication de la faculté des lettres, arts et sciences humaines de Nice, 1996, pp. 61-84; L.-G. TIN, Le Pantagruélion. Réflexions sur la notion d'exégèse littéraire, in Rabelais et la question du sens, ed. by J. CÉARD and M.-L. DEMONET, Genève, Droz, 2011 («Études rabelaisiennes», 49), pp. 113-124. However, due to limitations of space, a more detailed discussion must be reserved for another occasion.

(45) Mireille Huchon, in her edition of Rabelais's complete works, pertinently points out that «le Pantagruélion reprend les réflexions sur la mètis [cunning intelligence] mises en ouvre dans Pantagruel». Rabelais, Euvres complètes, Paris, Gallimard, 1994, p. 1451. 
befitting the inventor of sails ${ }^{46}$. According to the Tiers Livre's narrator, the Olympian gods were alarmed by human beings' unimpeded sailing and worried that they might eventually fly, enter the territory of the celestial signs and threaten their divine position. This observation could be interpreted as praise for human wisdom, but it actually indicates the problem of impious curiosity, for it implies that knowledge inflates people with arrogance and makes them think of themselves as equal to the gods ${ }^{47}$.

From this perspective, we can assume that the theme of the labyrinth reminded Rabelais of Daedalus and Icarus' flight from the Cretan labyrinth. In fact, according to Pliny, Icarus was the one who invented sails and Daedalus the mast and yards (see above). Furthermore, Ovid relates that Daedalus instructed his son to pay no attention whatsoever to the constellations ${ }^{48}$; Icarus, however, overcome by the desire to touch the heavenly realms $\mathrm{s}^{49}$ or the abodes of the stars ${ }^{50}$, ignored his father's instruction and fell into the sea. In this vein, Polydore Vergil, in his discussion on the invention of sailing, deplores humankind's recklessness and refers to Daedalus' flight: «God gave us the solid earth, an element well suited to sustain us, but we venture into sky and sea. Daedalus constructed his wings and approached heaven itself, did he not? $\gg^{51}$. These themes - human knowledge and ingenuity, invention of the sailboat, possibility of human flight and hubristic violation of the divine realm - also appear in the praise of Pantagruelion, which confirms Rabelais's interest in escaping the labyrinth.

In the final chapter, Rabelais suggests the ultimate way to proceed through the labyrinth of perplexity. Since he shares Erasmus' belief that true wisdom consists of always treating Christ as the model for one's life and especially the goal of all erudition, it is highly likely that the praise of the asbestine Pantagruelion is a praise of Christ or Christ's wisdom ${ }^{52}$. The ambiguous verb consommer (or consumer), skilfully interwoven into the text at the story's beginning and end, refocuses our attention on Christ's Passion and resurrection as the antithesis of the protagonist's perplexing quest. The Lord sacrificed himself on the cross, redeemed humanity's debts and descended into the underworld; however, he bound Satan in chains, freed the imprisoned souls and re-emerged unscathed rather than being consumed. Thus, by following him, we too can eventually escape the labyrinth ${ }^{53}$. Panurge's endless perplexity mirrors our own situation, but we are asked to take heart: «Bon espoir y gist au fond, comme en la bouteille de Pandora: non desespoir, comme on bussart des Danaïdes» (TL, 29). After all, church labyrinths once played an important part in Easter ceremonies. Rabelais was certainly aware that labyrinths symbolized not only prisons and the underworld but also victory and resurrection.

To review, the Reformation triggered a significant transition in the labyrinth's symbolic meaning, which became associated with this world rather than the underworld and with a battle within oneself rather than a duel between Christ and Satan.

(46) PLiny, Naturalis bistoria, 19.1. See also Polydore Vergil, De inventoribus rerum, 3.6.1.

(47) G. Defaux, Le Curieux, le glorieux et la sagesse du monde dans la première moitié du XVI siècle: l'exemple de Panurge, Lexington, French Forum Publishers, 1982, p. 194; E. DuvaL, The Design of Rabelais's "Tiers Livre", pp. 210-213; T. MAUS DE Rolley, Élévations. L'écriture du voyage aérien à la Renaissance, Genève, Droz, 2011, pp. 111-118.

(48) OvID, Metamorphoses, 8.206-207; Ars Amatoria, 2.55-56.

(49) Metamorphoses, 8.224.

(50) Ars Amatoria, 2.38-40.

(51) De inventoribus rerum, 3.15.1. POLYDORE Vergil, On Discovery, ed. and trans. by B.P. Co- penhaver, Cambridge, MA, Harvard University Press, 2002, p. 463.

(52) If the Pantagruelion represents the wisdom of the world and the asbestine Pantagruelion that of Christ, they are respectively analogous to $\mathrm{Hu}$ maine Discipline and Veritable Doctrine, allegorical characters in Bouchet's Le Labyrinthe de Fortune. Francois Rigolot comments that Panurge seems to follow Humaine Discipline and that Pantagruel seems to align himself with Veritable Doctrine. F. RigOLOT, Le labyrinthe du songe-mensonge, p. 122.

(53) Compare with Guillaume Budé's reflection on Christ's Harrowing of Hell. Budé, De transitu bellenismi ad christianismum, trans. into French by $\mathrm{M}$. LEBEL, Sherbrooke, Éditions Paulines, 1973, p. 76. 
Later, even the image of a heroic soldier began to disappear from labyrinths, being replaced by a solitary pilgrim. This change can be traced back to Erasmus' Enchiridion, which, using the labyrinth as a metaphor for this life, states that the battle with the Devil occurs within oneself: «Indeed, the battle array of the foe emerges from the depths of our own nature» (E, 62-63). The Tiers Livre is also positioned in the midst of this transition. It exhibits the structure of a church labyrinth and employs the themes of descent into the underworld and battle with Satan; however, it transposes them into our world and depicts the perplexity of a mortal figure similar to ourselves. By focusing on the labyrinth's association with both Christ's Passion and carnal passions, Rabelais created an incomparable textual labyrinth in which order and disorder successfully coexist as they did in visual labyrinths of the era. 


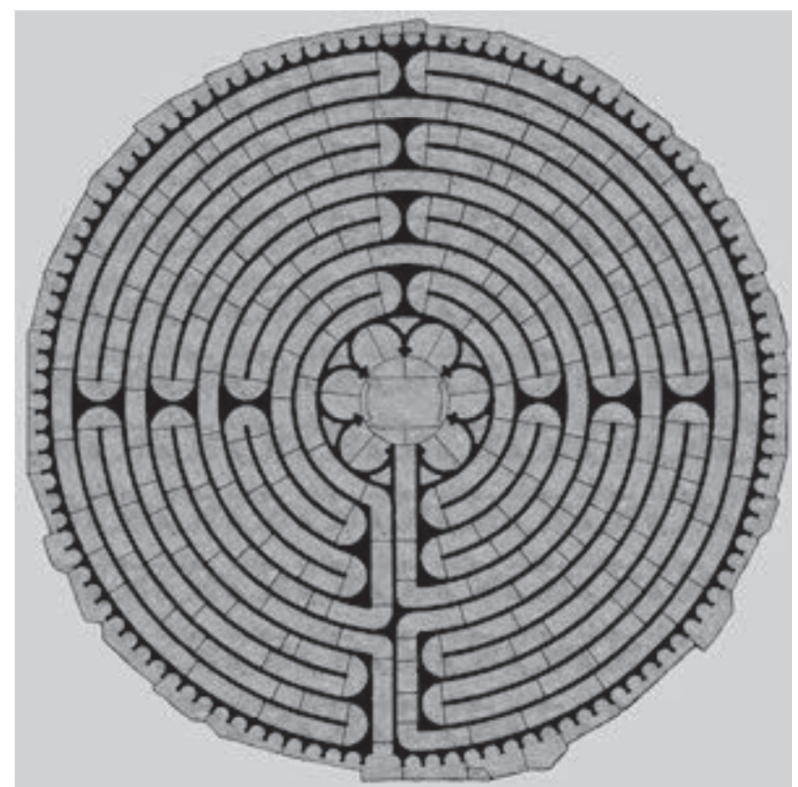

Figure 1:

Plan of the labyrinth in the nave of Chartres Cathedral (c. 1215). Courtesy of Jeff Saward. http://www.labyrinthos.net.

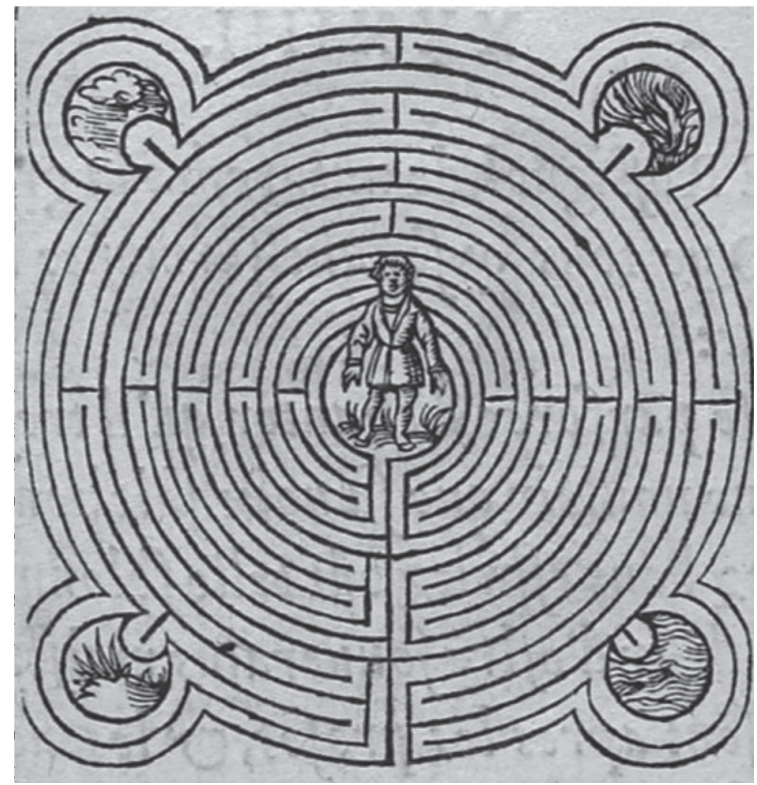

Figure 2:

Guillaume de La Perrière, Le Theatre des bons engins, Paris, Denis Janot, n.d. (1544), Glasgow University Library, SM686, fol. E8v. 